\title{
The Pool of Organic Carbon in the Soils of Russia
}

\author{
D. G. Schepaschenko ${ }^{a, b}$, L. V. Mukhortovac, A. Z. Shvidenko, ${ }^{a, c}$, and E. F. Vedrova ${ }^{c}$ \\ a International Institute for Applied Systems Analysis, Schlossplatz 1, A-2361, Laxenburg, Austria \\ ${ }^{b}$ Moscow State Forest University, Mytishchi-5, ul. Institutskaya 1, Moscow oblast, 141005Russia \\ ' Sukachev Institute of Forest, Siberian Branch, Russian Academy of Sciences, Akademgorodok, Krasnoyarsk, 660036 \\ Russia
}

\begin{abstract}
An automated information system making it possible to estimate spatial distribution of soil organic carbon pool with a high spatial resolution $(1 \mathrm{~km})$ has been developed. According to the obtained estimates, the total pool of organic carbon in the 1-m-deep soil layer on the territory of Russia reaches $317.1 \mathrm{Pg}$; the average organic carbon density in this layer for the entire Russia constitutes $19.2 \mathrm{~kg} \mathrm{C} / \mathrm{m}^{2}$. Of this amount, $14.4 \mathrm{Pg}$ (or $0.90 \mathrm{~kg} \mathrm{C} / \mathrm{m}^{2}$ ) is stored in the litter horizon. The developed algorithm allows us to refine the results with the acquisition of new data on soils, vegetation, and the degree of their disturbance, which is particularly important in the changing world.
\end{abstract}

Keywords: Organic matter, soil cover, information system, soils of Russia DOI: 10.1134/S1064229313020129

\section{INTRODUCTION}

Soil organic matter (SOM) represents a considerable pool of carbon with the turnover time from a year to tens of years (for vegetation residues) and from hundreds to thousands of years for soil humus. One of the major carbon sinks is confined to soils of northern Eurasia with its vast areas of tundras, wetlands, and boreal forests. These ecosystems are characterized by the retarded destruction of plant residues under conditions of a cold and humid climate [12]. The territory of Russia comprises $1 / 8.5$ part of the land surface. According to expert estimates, the soils of Russia contain about one-fifth of the world pool of soil carbon [12]. More accurate and reliable estimates of the total pool of organic matter in the soils of Russia and its geographic distribution are of great importance for modeling.

The pool of soil carbon is usually estimated for the upper 1-m-thick soil layer. The reasons for this are as follows: (1) in most of the soils, $90 \%$ of the total pool of organic carbon allocated in the first $1 \mathrm{~m}$ deep, despite of the entire soil profile reaching sometimes the depth of $2 \mathrm{~m}$ or more; (2) the carbon turnover mainly takes place in the upper soil layer; it is less pronounced at the depths of more than $1 \mathrm{~m}$ because of poor soil aeration and changes in the hydrothermic conditions retarding the rates of the organic matter mineralization; and (3) the existing soil maps are usually based on soil profile information with factual data on the organic carbon content to the depth of $1 \mathrm{~m} \mathrm{[12].}$

Permafrost-affected soils cover nearly $65 \%$ of Russia. The major biogeochemical processes there take place in the upper layer subjected to summer thawing; in some cases, its thickness does not exceed $20 \mathrm{~cm}$ (the thawing depth depends on the geomorphic position of the soil, the type of vegetation the green ground cover, and the thickness of organic horizons). However, even for these soils, the assessment of the soil carbon pool for the 1-m-thick soil layer makes sense, because the thawing depth is subjected to considerable alteration under the impact of the climate change, which is often most pronounced in the high latitudes.

The organic carbon pool in soils of Russia was estimated by soil scientists on the basis of data on typical soil profiles [44], or on the basis of averaged data from databases on the measured in situ soil characteristics [30]. The spatial distribution of different soils in these works was judged from the existing maps of ecological [51], administrative [39], and forest [30] regionalization of the territory, or from the soil maps on different scales [25, 42, 44, 47].

The aim of our study was to refine the existing estimates of the total pool of SOM in the Russian Federation and to analyze the spatial distribution of the soil carbon pools in dependence on the natural and anthropogenic factors (zonal climatic patterns, forest fires, etc.). We attempted to develop an automated information system on the basis of GIS technologies allowing one to perform calculations of the organic carbon distribution in the soils of Russia with due account for the vegetation and land use of particular territories. The developed method of the carbon assessment is aimed to combine the advantages of approaches used in the earlier studies and to apply more 
detailed information on the soils and vegetation. The created system should make it possible to provide spatially distributed estimates of the soil carbon content with necessary amendments upon acquisition of additional data on soils, vegetation, climate, and ecosystem disturbances. It should integrate the potentially available empirical data on the studied objects, including soil maps, descriptions of soil profiles, analytical data, and remote sensing data into a common information space.

\section{OBJECTS AND METHODS}

The following sources were used to calculate the organic carbon pool in soils:

(1) The soil map of the Russian Federation on a scale of 1:2.5 M [29] and a database on typical soil profiles for this map [49]. The database was updated by us on the basis of the explanatory note to this map [34];

(2) The database on the in situ measurements of organic carbon in the soils of Russia obtained from published sources. This database was used by us to take into account zonal and regional specificity of the soil carbon content of particular territories as well as the type of vegetation and land use;

(3) The map of dominant types of vegetation and land use [45] with a spatial resolution of $1 \mathrm{~km}^{2}$ that allows us to distribute the information on soils, vegetation, and the character of anthropogenic disturbances to the particular territories;

(4) The map of natural zones of the Russian Federation [49] that was used for correcting data on the soil carbon pool in dependence on the zonal features; and

(5) The administrative map of Russia [49] that was used for regional corrections of the SOM pool.

The initial data were organized as a geographic information system based on the ArcGIS and FireBird SQL software.

The pools of soil organic carbon were estimated separately for the litter layer and for the 1-m-thick soil layer under the litter. According to [15], the litter (or "on ground organic layer") is defined as a surface horizon of mineral soils that consists of the organic material (with the organic matter content of more than $35 \%$ of the mass of the litter (O) horizon). The thickness of the litter layer does not exceed $10 \mathrm{~cm}$. In organic soils, the litter layer includes the dead part of the mosses.

The database of typical soil profiles [49] includes soil characteristics (the thickness of soil horizons, the organic matter content, and the bulk density) and their ranges of the variation for each soil type. This database was used to calculate minimum and maximum organic carbon pool according to the following equation:

$$
C=\sum_{i=1}^{n}\left(\frac{H_{i}}{100} \frac{K_{C}}{100} \frac{\left(100-K_{S i}\right)}{100} D_{i} L_{i} K_{m e t} \times 10\right)
$$

where $\mathrm{C}$ denotes the pool of organic carbon in the 1-m-thick soil layer, or in the litter layer, $\mathrm{kg} / \mathrm{m}^{2} ; \mathrm{n}$ is the number of horizons in the soil profile; $H_{\mathrm{i}}$ is the organic matter content in the particular horizon, $\% ; K_{c i}$ is the carbon content in the organic matter, \%; $K_{s i}$ is the stone content in the horizon, \%; $D_{i}$ is the bulk density of the horizon, $\mathrm{g} / \mathrm{cm}^{3} ; L_{t}$ is the thickness of the horizon, $\mathrm{cm} ; \mathrm{K}_{\text {met }}$ is the correction factor for the organic matter determination on the basis of the wet combustion (Tyurin's) method (relative to the dry combustion method); and 10 is the conversion factor (from g/ $/ \mathrm{cm}^{2}$ to $\mathrm{kg} / \mathrm{m}^{2}$ ).

The mean carbon content $\left(K_{c}\right)$ in the organic matter of litter horizons was taken equal to $37.9 \%$ for all the soils. This value was somewhat corrected for the particular regions/zones; for forest soils, the dominant tree species was taken into account. The mean value and the correction factors were calculated on the basis of a number of publications $[6,7,10,17,24,27,36,37]$. It should be noted that some authors used a higher value of the carbon content in the litter horizons. For example, Rozhkov with coauthors [44] considered the carbon content in the litter horizons to be equal to $48 \%$.

The carbon content in the organic matter of mineral soil horizons in different types of soils varies from 53.4 to $58.0 \%[21,25]$.

A systematic error in the estimation of organic carbon is introduced by the wet combustion method of its determination. In dependence on the soil type, the values obtained by this method are by 13 to $34 \%$ lower than the values of the organic carbon content obtained by the dry combustion 
method [16]. The correction factors for different types of soils were determined on the basis of published data $[8,16,21,25]$.

It is known that the same type of soil can be found in several natural zones and different regions. As a rule, this fact is not taken into account in the estimates of soil carbon pools: the mean carbon content value of a typical soil profile is extrapolated over the entire area of this soil without consideration for the zonal conditions. The carbon content in soils is also affected by the type of vegetation, land use, and disturbances. To take into account these factors, we suggested corresponding correction coefficients:

$$
C=\left(C_{\min }+\frac{C_{\max }-C_{\min }}{2} K_{r e g} K_{s p}\right) K_{L U}
$$

where $\mathrm{C}$ is the corrected soil organic carbon pool estimation, $\mathrm{kg} / \mathrm{m}^{2}, \mathrm{C}_{\min }, \mathrm{C}_{\max }$ are the minimum and maximum contents of carbon in soils calculated according to Eq. (1) from the database on the typical soil profiles, $\mathrm{kg} / \mathrm{m}^{2}$ (minimum and maximum values of the thickness, bulk density, and the organic carbon content of the soil horizons are taken into account); $\mathrm{K}_{\text {reg }}$ is the regional correction coefficient (Table 2); $K_{\text {sp }}$ is the correction coefficient for forest areas that takes into account the effect of dominant tree species (Table 1); and $\mathrm{K}_{\mathrm{LU}}$ is the correction coefficient for different types of land use and ecosystem disturbances. A detailed description of the correction coefficients is given below.

Table 1. Correction coefficients for the organic carbon pools in litter horizons in dependence on the dominant tree species

\begin{tabular}{l|c|c}
\hline \multicolumn{1}{|c|}{ Tree species } & $\begin{array}{c}\text { Organic carbon content in the organic } \\
\text { matter, \% (parameter } K_{C} \text { in Eq. (1)) }\end{array}$ & $\begin{array}{c}\text { Coefficient to recalculate the reserves of } \\
\text { organic matter (parameter } K_{\text {sp }} \text { in Eq. (2)) }\end{array}$ \\
\hline Pine & 42 & 0.84 \\
Spruce & 37 & 0.96 \\
Fir & 41 & 1.45 \\
Larch & 36 & 0.88 \\
Cedar (Pinus sibirica) & 41 & 1.30 \\
Hardwood deciduous & 38 & 0.80 \\
Birch & 38 & 1.24 \\
Aspen & 35 & 0.58 \\
Other softwood deciduous & 38 & 0.94 \\
Dwarf pine (Pinus pumila) & 38 & 0.47 \\
\hline
\end{tabular}

Table 2. Correction coefficients ( $\mathrm{K}_{\text {reg }}$ in Eq. (2)) to calculate carbon pools in litter (nominator) and 1-m-thick soil layer (denominator) in dependence on the zone and region

\begin{tabular}{l|c|c|c|c}
\hline \multicolumn{1}{c|}{ Natural zone } & European part & West Siberia & Central Siberia & Far East \\
\hline Tundra & $0.53 / 0.60$ & $0.66 / 0.50$ & $0.77 / 0.40$ & $0.83 / 0.35$ \\
Forest-tundra and northern & $1.39 / 0.72$ & $1.36 / 0.60$ & $1.71 / 0.48$ & $1.01 / 0.42$ \\
taiga & $1.49 / 0.96$ & $0.63 / 0.80$ & $0.80 / 0.64$ & $1.00 / 0.56$ \\
Middle taiga & $1.15 / 1.20$ & $0.88 / 1.00$ & $0.86 / 0.80$ & $1.07 / 0.70$ \\
Southern taiga & $0.73 / 1.44$ & $1.47 / 1.20$ & $0.96 / 0.96$ & $1.10 / 0.84$ \\
Mixed and broadleaved forests & $0.71 / 1.68$ & $1.00 / 1.40$ & $0.86 / 1.12$ & - \\
Forest-steppe & $0.50 / 0.60$ & $0.50 / 0.50$ & $0.50 / 0.40$ & - \\
Deserts and semideserts & & &
\end{tabular}

Zonal specificity and the effect of tree species. To correct the estimation of organic matter pool in the litter horizons for the regional specificity, the bioclimatic zone (subzone), and the dominant tree species, a database with 1068 entries was developed. It was used to calculate correction coefficients for the major tree species $\left(K_{\text {sp }}\right.$, Table 1$)$ and, separately, for the region/bioclimatic zone (subzone) independently from the dominant tree species ( $\mathrm{K}_{\mathrm{reg}}$, Table 2$)$. The number of field measurements used to calculate $K_{p}$ varied from 7 to 560 (for different tree species); 
the number of field measurements used to calculate $\kappa_{\text {reg }}$ varied from 4 to 215 (for different region/zone combinations).

In terms of statistics, the amount and representativeness of the database collected by us are insufficient for the direct reliable calculation of soil carbon pool. Therefore, we could not manage without the typical soil profiles. However, our database made it possible to calculate correction coefficients for different zones, regions, types of vegetation, and ecosystem disturbances (such as grazing pressure, fires, etc.). The database on typical soil profiles was used to calculate the intervals for possible carbon pool in each of the soils displayed on the map. The obtained correction coefficients change the mean values of the soil carbon content typical of a given soil unit in dependence on the zone, regions, and type of vegetation and land use. However, our estimations lie within the range of the values (minimum-maximum) calculated for the certain soil unit according to Eq. (2).

The regional/zonal correction coefficient in Eq. (2) was applied in connection with soil type. In the case, when the given soil type is typical of a given zone/region, no correction coefficient was introduced. Thus, for each of the soil units shown on the map, the zone and region, where this soil is most widespread were determined. Correction coefficients were only introduced for the soils beyond their core area. For example, if a given soil is typical of the tundra zone in the European part of Russia (for this zone, the regional/zonal correction coefficient is equal to 0.60 (Table 2)), and this soil is also found in the northern taiga zone (with the correction coefficient of 0.72 ), then the correction coefficient to determine the carbon content in this soil in the northern taiga zone was calculated as follows: $K_{\text {reg }}=0.72 / 0.60=1.2$.

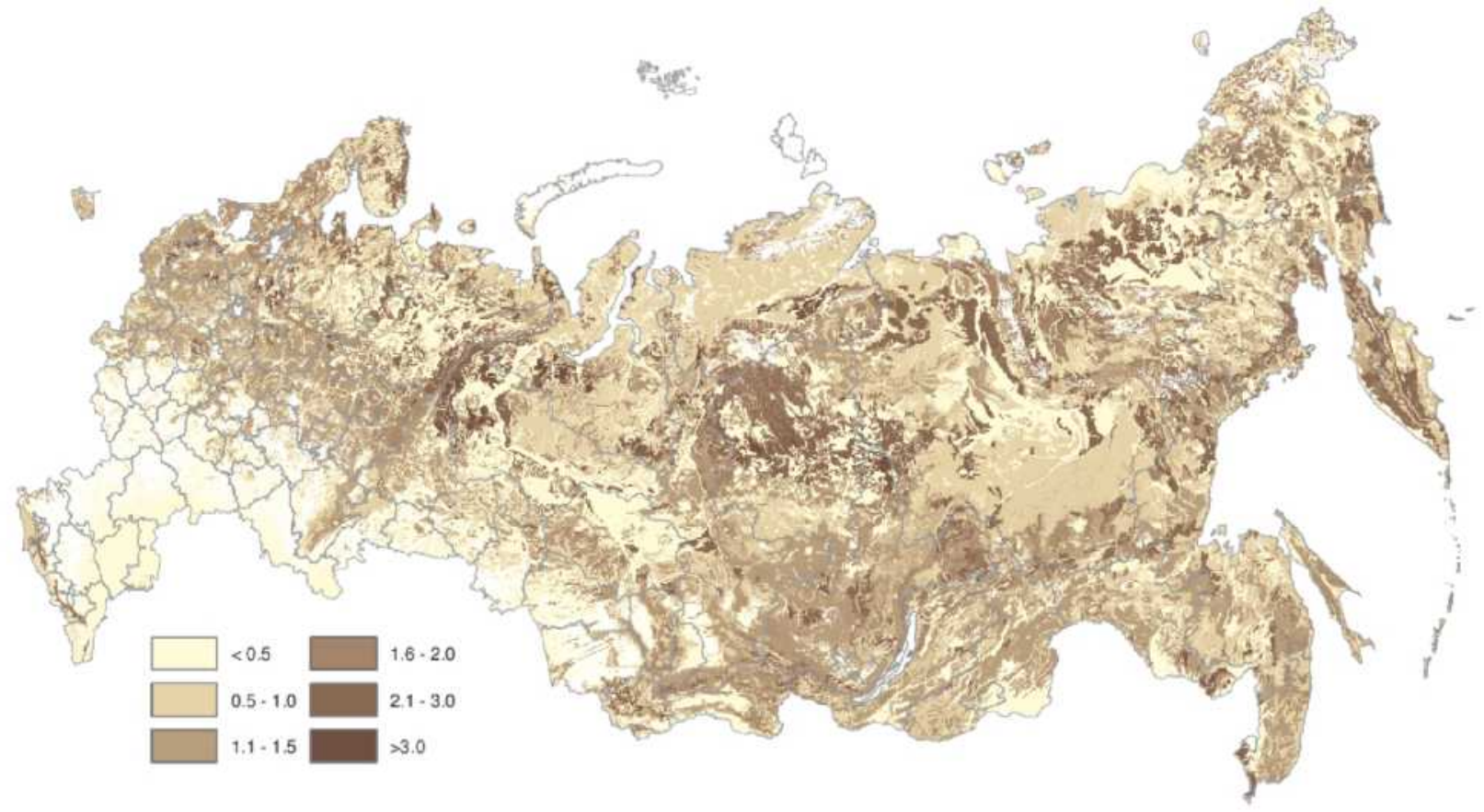

Fig. 1. The organic carbon pool in litter horizon, $\mathrm{kg} \mathrm{C} / \mathrm{m}^{2}$.

We have compared the results of calculation of the organic carbon pool in the soils of Russia with the use of the correction coefficients and without them. It was found that the resulting differences in the total carbon pools calculated by these two methods for the entire Russia do not exceed $1 \%$. However, application of the correction coefficients increases variability of the soil carbon estimations in dependence on the zone, region, and dominant tree species, though this variability remains within the minimum-maximum range of values calculated for each particular soil unit.

The effect of land use and disturbances of soils and vegetation. The character of land use and various kinds of ecosystem disturbances are important factors affecting the soil organic carbon pool. Spatial distribution of particular land use types and ecosystem disturbances were obtained 
from the land cover map of Russia [45]. Published data were used to find correction coefficients for ecosystem disturbances (e.g., for the use of grass lands as pastures) [3, 9, 18, 20, 33, 38, 40, 46]. The transformation of undisturbed steppe ecosystems into pastures leads to a decrease in the SOM pool in litter by $61 \%$; the amount of carbon in the 1 -m-thick soil layer is reduced by $25 \%$. For forest ecosystems, their transformation into pastures reduced the carbon pool in the forest litter and in the 1 -m-thick soil layer by 87 and $22 \%$, respectively. The soils of natural meadows transformed to hayfields lose about $30 \%$ of organic matter in the litter and about $5 \%$ in the upper 1 -m-thick soil layer.

For arable lands, the organic matter pool in the litter was taken equal to zero. A correction coefficient of 0.79 was applied for all the soils to calculate the pool of organic matter in the upper 1 -m-thick layer of soils of arable land compare to virgin land. This coefficient was obtained from the analysis of published data [11, 22, 35].

The economic crisis of the 1990s in Russia led to a considerable reduction of arable land that was converted into long-term fallow land $[1,2,26]$. Vegetation successions taking place on the abandoned arable land gradually lead to the restoration of natural cenoses typical of the particular regions $[11,19,22]$. For such lands, the correction factors for calculating the SOM carbon pool (relative to their values in the undisturbed natural soils) were taken equal to 0.50 for the litter horizons and to 0.87 for the mineral soil $[3,11,22,23]$.

Wild fires represent one more significant factor affecting the SOM pool and, particularly, litter. According to experimental data, fires may destroy from 14 to $100 \%$ of the litter pool in tundra and forest ecosystems $[5,13,43]$. The average correction factor to calculate the reserves of organic matter in the litter after fires was taken equal to $0.4\left(K_{L U}=0.4\right)$.

\section{RESULTS AND DISCUSSION}

The distribution of average carbon pool in the litter horizons of Russian soils is shown in Fig. 1 and Table 3 The total pool of organic carbon in the litter reaches $14.4 \mathrm{Pg}$, including $58 \%$ in the forest, $25 \%$ in the natural grasslands and shrublands, $7 \%$ in the sparse woodlands (with the canopy density of less than 0.3 ), $7 \%$ in the forestless wetland, and $3 \%$ in the other land categories (including agricultural land and burnt areas). About one-half (49\%) of the carbon pool of litter is accumulated in the middle taiga zone; $17 \%$, in the tundra zone; $17 \%$, in the northern taiga zone; $12 \%$, in the southern taiga zone, and $5 \%$, in the zones of mixed forests, forest-steppes, and steppes. The carbon pool of litter in the Asian part of Russia comprises $83 \%$ of the total litter pool in Russian soils; the remaining $17 \%$ are found in the European part of Russia.

Table 3. Distribution of average pool of organic carbon in the litter by different regions, zones, and land categories, $\mathrm{kg} \mathrm{C} / \mathrm{m}^{2}$

\begin{tabular}{|c|c|c|c|c|c|c|c|c|c|}
\hline Zone & Forest & $\begin{array}{c}\text { Open } \\
\text { Wood- } \\
\text { land }\end{array}$ & $\begin{array}{c}\text { Burnt } \\
\text { area }\end{array}$ & $\begin{array}{l}\text { Hayfield } \\
\text { and } \\
\text { pasture }\end{array}$ & Fallow & Wetland & $\begin{array}{c}\text { Grassland } \\
\text { and shrubs }\end{array}$ & Average & $\begin{array}{l}\text { Total, } \\
\text { Tg C }\end{array}$ \\
\hline \multicolumn{10}{|c|}{ European part } \\
\hline Arctic & & & & & & & 0.43 & 0.43 & 1 \\
\hline Tundra & 0.86 & 1.03 & 0.49 & 0.28 & 0.15 & 0.93 & 1.15 & 1.01 & 255 \\
\hline $\begin{array}{l}\text { Forest tundra, open } \\
\text { woodland, and northern } \\
\text { taiga }\end{array}$ & 0.97 & 1.00 & 0.54 & 0.93 & 0.24 & 0.85 & 1.26 & 0.95 & 465 \\
\hline Middle taiga & 1.04 & 1.08 & 0.59 & 0.61 & 0.49 & 0.87 & 1.12 & 1.01 & 663 \\
\hline Southern taiga & 0.92 & 0.97 & 0.48 & 0.50 & 0.47 & 0.64 & 0.83 & 0.75 & 698 \\
\hline Mixed forests & 0.91 & 0.80 & 0.56 & 0.36 & 0.35 & 0.66 & 0.62 & 0.46 & 170 \\
\hline Steppe & 0.50 & 0.56 & 0.21 & 0.17 & 0.17 & 0.83 & 0.38 & 0.12 & 111 \\
\hline Semideserts and deserts & 0.39 & 0.56 & 0.17 & 0.12 & 0.14 & 0.38 & 0.29 & 0.16 & 25 \\
\hline Average & 0.95 & 0.97 & 0.47 & 0.26 & 0.34 & 0.85 & 0.76 & 0.64 & 2388 \\
\hline
\end{tabular}




\begin{tabular}{|c|c|c|c|c|c|c|c|c|c|}
\hline Zone & Forest & $\begin{array}{c}\text { Open } \\
\text { Wood- } \\
\text { land }\end{array}$ & $\begin{array}{c}\text { Burnt } \\
\text { area }\end{array}$ & $\begin{array}{l}\text { Hayfield } \\
\text { and } \\
\text { pasture }\end{array}$ & Fallow & Wetland & $\begin{array}{c}\text { Grassland } \\
\text { and shrubs }\end{array}$ & Average & $\begin{array}{l}\text { Total, } \\
\text { Tg C }\end{array}$ \\
\hline \multicolumn{10}{|c|}{ Asian part } \\
\hline Arctic & & & & & & & 0.75 & 0.75 & 2 \\
\hline Tundra & 1.14 & 1.11 & 0.77 & 0.54 & 0.81 & 0.49 & 1.13 & 1.02 & 2190 \\
\hline $\begin{array}{l}\text { Forest tundra, open } \\
\text { woodland, and northern } \\
\text { taiga }\end{array}$ & 1.14 & 1.17 & 0.77 & 0.29 & 0.26 & 0.78 & 1.38 & 1.12 & 2046 \\
\hline Middle taiga & 1.02 & 1.20 & 0.69 & 0.60 & 0.38 & 0.62 & 1.24 & 1.02 & 6345 \\
\hline Southern taiga & 0.91 & 0.90 & 0.52 & 0.46 & 0.32 & 0.60 & 0.90 & 0.82 & 988 \\
\hline Mixed forests & 1.26 & 0.94 & 0.54 & 0.38 & 0.45 & 0.83 & 0.87 & 0.94 & 248 \\
\hline Steppe & 0.82 & 0.76 & 0.37 & 0.23 & 0.21 & 0.67 & 0.62 & 0.30 & 190 \\
\hline Semideserts and deserts & 0.48 & 0.45 & 0.22 & 0.19 & 0.13 & 0.43 & 0.55 & 0.29 & 14 \\
\hline Average & 1.03 & 1.17 & 0.70 & 0.35 & 0.31 & 0.62 & 1.18 & 0.98 & 12023 \\
\hline \multicolumn{10}{|c|}{ Total Russia } \\
\hline Arctic & & & & & & & 0.63 & 0.63 & 3 \\
\hline Tundra & 1.08 & 1.09 & 0.77 & 0.49 & 0.51 & 0.57 & 1.13 & 1.02 & 2445 \\
\hline $\begin{array}{l}\text { Forest tundra, open } \\
\text { woodland, and northern } \\
\text { taiga }\end{array}$ & 1.10 & 1.15 & 0.77 & 0.37 & 0.25 & 0.80 & 1.38 & 1.08 & 2511 \\
\hline Middle taiga & 1.02 & 1.19 & 0.68 & 0.60 & 0.40 & 0.65 & 1.24 & 1.02 & 7008 \\
\hline Southern taiga & 0.92 & 0.96 & 0.52 & 0.48 & 0.44 & 0.61 & 0.87 & 0.79 & 1686 \\
\hline Mixed forests & 1.11 & 0.82 & 0.54 & 0.37 & 0.40 & 0.80 & 0.70 & 0.66 & 418 \\
\hline Steppe & 0.71 & 0.61 & 0.32 & 0.20 & 0.19 & 0.68 & 0.44 & 0.20 & 302 \\
\hline Semideserts and deserts & 0.45 & 0.53 & 0.20 & 0.13 & 0.14 & 0.42 & 0.33 & 0.19 & 39 \\
\hline Average & 1.01 & 1.14 & 0.69 & 0.30 & 0.33 & 0.66 & 1.14 & 0.90 & \\
\hline Total, Tg C & 8323 & 971 & 164 & 274 & 116 & 955 & 3608 & & 14411 \\
\hline
\end{tabular}

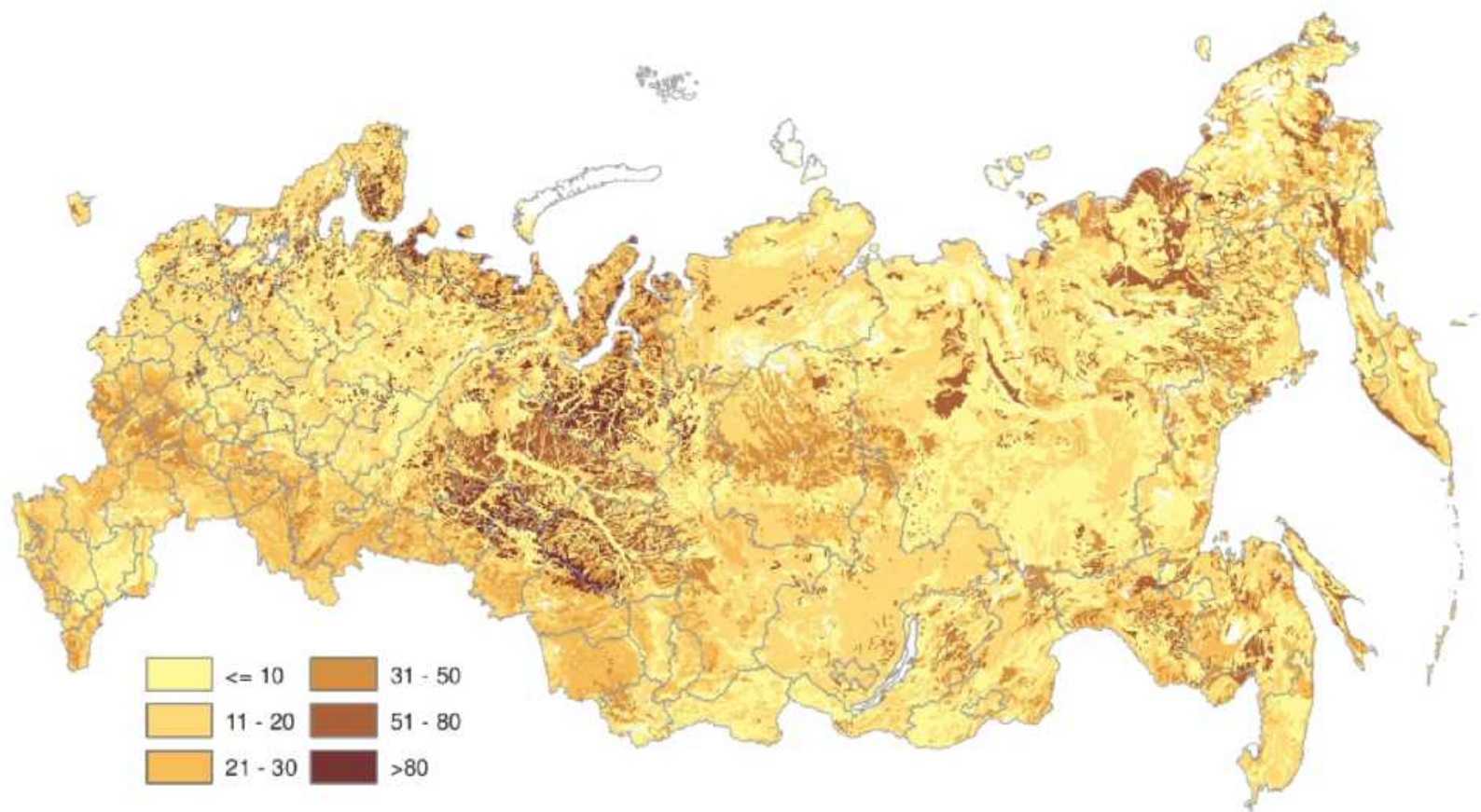

Fig. 2. The pool of organic carbon in litter and in the 1 - $\mathrm{m}$-thick soil layer, $\mathrm{kg} \mathrm{C} / \mathrm{m}^{2}$.

Our estimation of the total carbon pool of litter (14.4 Pg C) is within the range of other [44] estimates. Thus, Rozhkov with coauthors estimated the carbon pool in the litter horizons of Russia at $18.9 \pm 4.4 \mathrm{Pg} \mathrm{C}$. Somewhat larger data obtained by these authors could be explained by the fact that 
they used a higher percent of carbon in the litter. In the work by Chestnykh with coauthors [31], the carbon pool in the litter under forest areas ( 733.15 million ha) was estimated at $5.26 \mathrm{Pg}$, which constitutes $72 \%$ of the value obtained by us for forest areas. This bias can be explained by the differences in the methods of calculation. Chestnykh with coauthors gathered from scientific publications a database with about 900 in situ litter carbon stock measurements. The calculated average SOM pool in the litter horizons for 12 regions and further subdivided the forests of Russia according to the dominant tree species. Overall, they obtained 75 averaged values for the whole country. However, they did not check the representativeness of data in their database, which could lead to some biased estimates. For example, data on larch stands in the middle taiga zone in their database include 8 entries with the range of litter carbon pool from 4.6 to $12.7 \mathrm{t} \mathrm{C} /$ ha (on the average, $7.3 \mathrm{t} / \mathrm{ha}$ ). According to our calculations, middle-taiga larch stands occupy the area of 205 million ha and grow on more than 50 different soil units. Our average estimate for the litter reserves in this type of forests is $9.6 \mathrm{t} \mathrm{C} /$ ha with variations from 1.6 to $26.0 \mathrm{t} \mathrm{C} /$ ha for different soil types.

According to our estimates, the total pool of organic carbon in the litter and in the underlying 1-m- thick soil layer for the entire Russia reaches 317.1 Pg C (Table 4, Fig. 2). This result is relatively close to other estimates obtained in the past 15 years (Table 5); the differences for the entire country are within $5-7 \%$. However, larger differences are observed for forest areas. The total SOM carbon pool of Russian forests obtained by other authors vary from 55 to $115 \%$ of the value obtained by us. Somewhat lower values $[30,48]$ could be explained by the underestimation of the area of peat soils in the forests. Higher results [44] could be due to the absence of correction for disturbances (in particular, wild fires). The carbon content $\left(27.3 \mathrm{~kg} \mathrm{C} / \mathrm{m}^{2}\right)$ in permafrost-affected soils of Eurasia obtained by Tarnocai with coauthors [50] is by $30 \%$ higher than the corresponding value obtained in our work. In this case, however, direct comparisons are not quite correct, because the database used in [50] also included data on the soils of Scandinavia and Tibet.

In general, the soils of forest ecosystems contain $46 \%$ of the total organic carbon pool in the soil cover of Russia. The contributions of forest ecosystems to the total soil carbon pool in the Asian and European parts of Russia are different (48 and 37\%, respectively), which reflects different percentages of forests in these regions. An opposite situation is observed for the soils of agricultural fields ( $20 \%$ in the European part of Russia and $2 \%$ in the Asian part of Russia), which is explained by the lower percentage of agricultural lands in Siberia and the Far East, because the absolute values of the carbon content in the upper 1- m-thick layer of agricultural soils in the European and Asian parts of Russia are approximately similar.

The contribution ofwetland areas to the total SOM pool averages $20 \%$ with $16 \%$ in the European part and $21 \%$ in the Asian part of the country.

Higher stock of litter in the Asian part of Russia can be explained by the less favorable conditions for the organic matter decomposition because of the long and severe winters and short growing seasons with relatively low temperatures. Under these conditions, the accumulation of partially decomposed plant residues on the soil surface is clearly pronounced. Relatively high litter pool under open woodlands may be related to the high biomass production by the ground cover on open spaces. The contribution of the ground cover to the litter pool is significant in northern ecosystems.

Higher pool of litter in the grassland and shrub ecosystems of the middle and northern taiga and forest- tundra in comparison with more southern forest ecosystems is explained by the high annual production of the green biomass of herbs in these cenoses. According to [4], the production of herbaceous vegetation in the northern forest ecosystems may reach $0.73 \mathrm{~kg} / \mathrm{m}^{2}$ per year; it exceeds the production of herbaceous vegetation in typical forest $(0.17$ to $0.31 \mathrm{~kg} / \mathrm{m} 2)$ by almost two times. 
Table 4. Distribution of average stock of organic carbon $\left(\mathrm{kg} \mathrm{C} / \mathrm{m}^{2}\right)$ in soil (litter + underlying 1-m-thick of soil) by natural zones and land categories

\begin{tabular}{|c|c|c|c|c|c|c|c|c|c|c|c|}
\hline \multirow[b]{2}{*}{ Zone } & \multicolumn{9}{|c|}{ Average carbon content, $\mathrm{kg} \mathrm{C} / \mathrm{m}^{2}$ by land classes } & \multirow[b]{2}{*}{$\begin{array}{l}\text { Average, } \\
\mathrm{kg} \mathrm{C} / \mathrm{m}^{1}\end{array}$} & \multirow[b]{2}{*}{$\begin{array}{l}\text { Total, } \\
\text { PgC }\end{array}$} \\
\hline & Barrens* & Forest & $\begin{array}{l}\text { Open } \\
\text { woodland }\end{array}$ & $\begin{array}{l}\text { Burnt } \\
\text { area }\end{array}$ & Arable & $\begin{array}{l}\text { Hayfields } \\
\text { and } \\
\text { pastures }\end{array}$ & Fallow & Wetland & $\begin{array}{l}\text { Grassland } \\
\text { and shrubs }\end{array}$ & & \\
\hline \multicolumn{11}{|c|}{ European part } & \\
\hline Arctic & 0.05 & & & & & & & & 1.74 & 0.11 & 0.0 \\
\hline Tundra & 0.61 & 28.85 & 33.41 & 4.17 & 0.00 & 18.15 & 6.12 & 44.48 & 17.06 & 27.57 & 7.5 \\
\hline $\begin{array}{l}\text { Forest tundra, open } \\
\text { woodland, and }\end{array}$ & 4.26 & 19.68 & 19.09 & 14.97 & 10.59 & 9.95 & 8.91 & 40.19 & 18.07 & 24.22 & 11.9 \\
\hline Middle taiga & 2.42 & 13.75 & 15.96 & 9.97 & 34.65 & 9.66 & 13.47 & 38.67 & 14.19 & 15.59 & 10.2 \\
\hline Southern taiga & 3.06 & 14.59 & 13.66 & 12.85 & 10.85 & 9.93 & 9.21 & 64.64 & 14.96 & 14.74 & 13.7 \\
\hline Mixed forests & 7.02 & 17.12 & 17.90 & 20.43 & 19.80 & 16.67 & 19.01 & 38.18 & 19.65 & 18.39 & 6.8 \\
\hline Steppe & 7.71 & 25.42 & 27.16 & 25.72 & 24.49 & 21.52 & 24.30 & 26.86 & 21.73 & 23.58 & 21.3 \\
\hline $\begin{array}{l}\text { Semideserts and } \\
\text { deserts }\end{array}$ & 2.95 & 17.95 & 23.01 & 14.21 & 7.18 & 7.42 & 7.92 & 7.49 & 7.96 & 7.69 & 1.2 \\
\hline Average & 0.52 & 16.21 & 20.25 & 13.87 & 22.19 & 15.16 & 15.73 & 43.24 & 17.51 & 18.99 & 72,6 \\
\hline \multicolumn{12}{|c|}{ Asian part } \\
\hline Arctic & 0.41 & & & & & & & & 9.47 & 1.14 & 0.0 \\
\hline Tundra & 2.06 & 18.16 & 20.71 & 13.84 & 0.00 & 10.40 & 7.22 & 38.98 & 13.82 & 16.73 & 40.6 \\
\hline $\begin{array}{l}\text { Forest tundra, open } \\
\text { woodland, and } \\
\text { northern taiga }\end{array}$ & 5.25 & 22.00 & 27.11 & 11.06 & 9.27 & 12.50 & 12.95 & 44.83 & 14.26 & 24.52 & 45.0 \\
\hline Middle taiga & 2.78 & 15.87 & 14.88 & 15.22 & 13.65 & 11.96 & 15.01 & 45.71 & 14.41 & 17.23 & 107.7 \\
\hline Southern taiga & 5.00 & 22.31 & 29.44 & 27.72 & 17.50 & 14.76 & 17.44 & 62.95 & 24.73 & 26.19 & 31.7 \\
\hline Mixed forests & 5.21 & 16.73 & 35.66 & 25.85 & 21.08 & 17.97 & 18.41 & 36.17 & 24.16 & 18.66 & 4.9 \\
\hline Steppe & 5.47 & 22.70 & 28.43 & 24.10 & 23.93 & 19.91 & 24.06 & 19.01 & 20.86 & 21.86 & 13.8 \\
\hline $\begin{array}{l}\text { Semideserts and } \\
\text { deserts }\end{array}$ & 1.01 & 17.15 & 8.14 & 11.33 & 18.65 & 15.84 & 19.66 & 13.69 & 10.24 & 14.72 & 0.7 \\
\hline Average & 2.07 & 17.96 & 19.94 & 14.93 & 22.50 & 17.10 & 19.52 & 44.39 & 14.35 & 19.24 & 244.5 \\
\hline
\end{tabular}




\begin{tabular}{|c|c|c|c|c|c|c|c|c|c|c|c|}
\hline \multirow[b]{2}{*}{ Zone } & \multicolumn{9}{|c|}{ Average carbon content, $\mathrm{kg} \mathrm{C} / \mathrm{m}^{2}$ by land classes } & \multirow[b]{2}{*}{$\begin{array}{l}\text { Average, } \\
\mathrm{kg} \mathrm{C} / \mathrm{m}^{1}\end{array}$} & \multirow[b]{2}{*}{$\begin{array}{l}\text { Total, } \\
\text { PgC }\end{array}$} \\
\hline & Barrens* & Forest & $\begin{array}{l}\text { Open } \\
\text { woodland }\end{array}$ & $\begin{array}{l}\text { Burnt } \\
\text { area }\end{array}$ & Arable & $\begin{array}{l}\text { Hayfields } \\
\text { and } \\
\text { pastures }\end{array}$ & Fallow & Wetland & $\begin{array}{l}\text { Grassland } \\
\text { and shrubs }\end{array}$ & & \\
\hline \multicolumn{11}{|c|}{ Total Russia } & \\
\hline Arctic & 0.20 & & & & & & & & 6.54 & 0.56 & 0.0 \\
\hline Tundra & 1.96 & 20.24 & 24.31 & 13.72 & 0.00 & 11.92 & 6.71 & 39.99 & 14.02 & 17.83 & 48.1 \\
\hline \multirow{3}{*}{$\begin{array}{l}\text { Forest tundra, open } \\
\text { woodland, and } \\
\text { northern taiga } \\
\text { Middle taiga }\end{array}$} & & & & & & & & & & & 56.8 \\
\hline & 5.22 & 21.44 & 26.24 & 11.07 & 9.75 & 12.16 & 10.90 & 43.40 & 14.37 & 24.45 & \\
\hline & 2.78 & 15.62 & 14.91 & 15.19 & 18.95 & 11.64 & 14.77 & 44.92 & 14.41 & 17.07 & 117.9 \\
\hline Southern taiga & 4.09 & 19.38 & 15.65 & 25.86 & 13.11 & 11.64 & 11.01 & 63.26 & 20.91 & 21.22 & 45.4 \\
\hline Mixed forests & 6.39 & 16.90 & 20.08 & 25.02 & 20.02 & 17.09 & 18.75 & 36.50 & 20.98 & 18.50 & 11.7 \\
\hline Steppe & 6.26 & 23.61 & 27.44 & 24.63 & 24.33 & 20.70 & 24.21 & 19.79 & 21.49 & 22.87 & 35.1 \\
\hline $\begin{array}{l}\text { Semideserts and } \\
\text { deserts }\end{array}$ & 1.83 & 17.39 & 19.12 & 12.27 & 13.31 & 8.95 & 10.24 & 12.08 & 8.33 & 9.36 & 1.9 \\
\hline Average & 1.82 & 17.60 & 19.99 & 14.92 & 22.28 & 16.05 & 17.14 & 44.17 & 14.63 & 19.19 & \\
\hline Total, Pg C & 0.8 & 144.5 & 17.0 & 3.5 & 20.4 & 14.8 & 6.0 & 63.9 & 46.2 & & 317.1 \\
\hline
\end{tabular}


Table 5. The stock of organic carbon in Russian soils as estimated by different authors

\begin{tabular}{|c|c|c|c|c|}
\hline \multicolumn{4}{|c|}{ Stock of organic carbon } & \multirow{3}{*}{ Source } \\
\hline \multicolumn{2}{|c|}{ in litter } & \multicolumn{2}{|c|}{ in a 1-m-thick soil layer } & \\
\hline \multirow[t]{2}{*}{$\mathrm{kg} \mathrm{C} / \mathrm{m}^{2}$} & $\begin{array}{l}\text { relative to our } \\
\text { estimate, \% }\end{array}$ & $\mathrm{kg} \mathrm{C} / \mathrm{m}^{2}$ & $\begin{array}{l}\text { relative to our } \\
\text { estimate, \% }\end{array}$ & \\
\hline & & \multicolumn{2}{|c|}{ Total Russia } & \\
\hline \multirow[t]{3}{*}{1.03} & 114 & 22.1 & 115 & Vinson and Kolchugina, 1993 [51] \\
\hline & & 17.3 & 90 & Orlov et al., 1996 [25] \\
\hline & & 20.6 & 107 & Rozhkov et al., 1996 [44] \\
\hline \multirow[t]{2}{*}{1.04} & 116 & 18.0 & 94 & Nilsson et al., 2000 [42] \\
\hline & & 18.3 & 95 & Stolbovoi, 2002 [47] \\
\hline \multirow[t]{4}{*}{0.90} & 100 & 19.2 & 100 & $\begin{array}{l}\text { Results obtained by the authors in this } \\
\text { work }\end{array}$ \\
\hline & & \multicolumn{2}{|c|}{ Forested land } & \\
\hline & & 17.0 & 97 & Orlov et al., 1996 [25] \\
\hline & & 20.3 & 115 & Rozhkov et al., 1996 [44] \\
\hline 1.80 & 178 & 9.6 & 55 & Alexeyev and Birdsey, 1998 [39] \\
\hline \multirow[t]{4}{*}{1.50} & 148 & 11.5 & 65 & Nilsson et al., 2000 [42] \\
\hline & & 14.8 & 84 & Utkin et al., 2001 [28] \\
\hline & & 15.9 & 90 & Shvidenko et al., 2003 [32] \\
\hline & & 11.5 & 65 & Stolbovoi, 2006 [48] \\
\hline \multirow[t]{2}{*}{0.72} & 71 & 16.2 & 92 & Chestnykh et al., 2004, $2007[30,31]$ \\
\hline & & 15.9 & 90 & Zamolodchikov et al., 2005 [14] \\
\hline 1.01 & 100 & 17.6 & 100 & $\begin{array}{l}\text { Results obtained by the authors in this } \\
\text { work }\end{array}$ \\
\hline
\end{tabular}

In general, the carbon pool in the litter regularly increase from the south to the north, up to the northern taiga zone. This regularity is not observed for the organic matter pool in the 1-m-thick soil layer. Only $5-6 \%$ of the total soil carbon pool is allocated in litter horizons, so that doesn't affect much total SOM spatial distribution. Wetlands contain the highest average amount of organic carbon in the 1-m-thick soil layer $\left(44.4 \mathrm{~kg} / \mathrm{m}^{2}\right)$. Arable lands are also characterized by a relatively high content of organic matter $\left(22.5 \mathrm{~kg} \mathrm{C} / \mathrm{m}^{2}\right.$ on the average). This is explained by the fact that the most fertile and humus-rich soils were the first to be involved in agriculture. The areas with a large percentage of peatlands (West Siberia and the Kolyma River valley) are characterized by the very high content of organic matter $\left(>80 \mathrm{~kg} \mathrm{C} / \mathrm{m}^{2}\right)$. Low-fertile soddy calcareous soils in the south of Yakutia and brown solonetzic soils of Kalmykia are poor in the organic matter. The map of the soil carbon pool with a spatial resolution of $1 \mathrm{~km}^{2}$ is available from the website http://russia.geo-wiki.org. On the starting page of this site, visitors are suggested to register, or they can take a test trial ("Try as guest"). Then, free software Google Earth has to be installed. After the installation, a corresponding map (Soil Carbon of Russia) can be selected and viewed.

\section{CONCLUSIONS}

The developed information system makes it possible to estimate the total organic carbon pool in Russian soils and to analyze its spatial distribution. This system is based on a large set of available information sources: the soil map, the database of in situ measurements on different types of soils, the materials of forest and land surveys, and the remote sensing data. The total pool of organic carbon in the soils of Russia is estimated at $317.1 \mathrm{Pg} \mathrm{C}$ with the average carbon density of $19.2 \mathrm{~kg}$ $\mathrm{C} / \mathrm{m}^{2}$. Of this amount, $14.4 \mathrm{Pg} \mathrm{C}\left(0.90 \mathrm{~kg} \mathrm{C} / \mathrm{m}^{2}\right)$ is stored in the litter. These estimates seem to be the most accurate for the present time, though their accuracy cannot be evaluated by formal statistical methods. The created system can reproduce spatially distributed estimates of the soil carbon pools with a high spatial resolution $\left(1 \mathrm{~km}^{2}\right)$ and can be refined with due account for new data on the soils, 
vegetation, and their disturbances.

\section{REFERENCES}

1. O. A. Antsiferova, "Indicative Meaning of Young Tree and Shrub Growth on Young Fallows in Kaliningrad Oblast," Izvest. KGTU, No. 8, 111-116 (2005).

2. O. A. Antsiferova, "Dynamics of Fertility Indices on Fallow Lands of Kaliningrad Oblast," Agrokhim. Vestn. No. 2, 2-3 (2008).

3. M. A. Babaeva, Extended Abstract of Candidate's Dissertation in Biology (Rostov-on-Don, 2005).

4. N. I. Bazilevich, Biological Productivity of Ecosystems in Northern Eurasia (Nauka, Moscow, 1993) [in Russian].

5. N. Bezkorovainaya, G. A. Ivanova, P. A. Tarasov, etal., "Pyrogenic Transformation of Soils under Pine Stands of the Middle Taiga in the Krasnoyarsk Region," Sib. Ekolog. Zh., No. 1, 143-152 (2005).

6. P. Bien'kovski, A. A. Titlyanova, and S. V. Shibareva, "Transformation Processes in Litters of Boreal Forests," Sib. Ekolog. Zh., No. 10 (2003).

7. E. F. Vedrova, "Transformation of Plant Residues in 25-Yfear-Old Stands of the Major Forest-Forming Tree Species of Siberia," Lesovedenie, No. 4, 13-21 (1995).

8. GOST 26213-91. Soils. Methods to Determine the Organic Matter Content (Moscow, 1992) [in Russian].

9. M. Gadzhiev, A. Yu. Korolyuk, A. A. Titlyanova, Steppes of Central Asia (Izd. SO RAN, Novosibirsk, 2002) [in Russian].

10. L. A. Grishina, Biological Turnover and Its Role in Soil Formation (Izd. Mosk. Gos. Univ., Moscow, 1974) [in Russian].

11. N. V. Evseeva, Extended Abstract of Candidate's Dissertation in Biology (Rostov-on-Don, 2002).

12. G. A. Zavarzin and V. N. Kudeyarov, "Soil as the Major Source of Carbon Dioxide and Organic Carbon Rervoir in Russia," Vsstn. Ross. Akad. Nauk, 76 (1), 14-29 (2006).

13. D. G. Zamolodchikov, D. V. Karelin, and A. I. Ivashchenko, "Postfire Changes in the Carbon Cycle in Southern Tundra," Ekologiya, No. 4, 272-276 (1998).

14. D. G. Zamolodchikov, A. I. Utkin, G. N. Korovin, et al., "Dynamics of the Pools and Fluxes of Carbon in Russian Forests," Ekologiya, No. 5, 323-333 (2005).

15. Classification and Diagnostic System of Russian Soils (Oikumena, Smolensk, 2004) [in Russian].

16. V. M. Kogut and A. S. Frid, "A Comparative Analysis of the Methods Used to Determine the Humus Content in Soils" Pochvovedenie, No. 9, 119-123 (1993).

17. N. N. Koshurnikova, Extended Abstract of Candidate's Dissertation in Biology (Krasnoyarsk, 2007).

18. V. D. Kumacheva, Extended Abstract of Candidate's Dissertation in Biology (Rostov-on-Don, 2008).

19. N. Kurganova, Extended Abstract of Doctoral Dissertation in Biology (Moscow, 2010).

20. Ch. S. Kyrgys, Extended Abstract of Candidate's Dissertation in Biology (Tomsk, 2004).

21. Lishtvan, E. T. Bazin, N. I. Gamayunov, and A. A. Terent'ev, A.A., Physics and Chemistry of Peat (Nedra, Moscow, 1989).

22. V. O. Lopes de Gerenyu, I. N. Kurganova, A. M. Ermolaev, et al., "Changes in the Organic Matter Pools upon Self-Rehabilitation of Plowed Chernozems," Agrokhimiya, No. 5, 5-12 (2009).

23. L. R. Mukina, A. A. Shpedt, and G. E. Zolotukhin, "The Humus State of Fallow Chernozems in the Krasnoyarsk Region," in Soil as a Link between Natural and Anthropogenically Transformed Ecosystems, (Materials of the II Int. Conf. Devoted to the 75th Anniversary of the Soil Science Department in Irkutsk State University) (Irkutsk, 2006), pp. 217-219 [in Russian].

24. L. V. Mukhortova, Extended Abstract of Candidate's Dissertation in Biology (Krasnoyarsk, 2001).

25. D. S. Orlov, O. N. Biryukova, and N. I. Sukhanova, Organic Matter in Soils of the Russian Federation (Nauka, Moscow, 1996) [in Russian].

26. Pools and Fluxes of Carbon in Terrestrial Ecosystems of Russia, Ed. by V. N. Kudeyarov and G. A. Zavarzin (Nauka, Moscow, 2007) [in Russian].

27. L. E. Rodin, N. P. Remezov, and N. I. Bazilevich, Methodological Guidelines to Study the Dynamics of the Biological Turnover in Phytocenoses (Nauka, Leningrad, 1968) [in Russian].

28. Utkin, D. G. Zamolodchikov, O. V. Chestnykh, et al., "Forests of Russia as a Reservoir for the Organic Carbon in the Biosphere," Lesovedenie, No. 5, 8-23 (2001).

29. V. M. Fridland, Soil Map of the Russian Federation, 1:2.5MScale (GUGK, Moscow, 1988) [in Russian].

30. O. V. Chestnykh, D. G. Zamolodchikov, and A. I. Utkin, "Total Reserves of the Biological Carbon and Nitrogen in Soils of Russian Forests," Lesovede- nie, No. 4, 30-42 (2004).

31. O. V. Chestnykh, V. A. Lyzhin, and A. V. Koksharova, "Carbon Reserves in Litters of Russian Forests," Lesovedenie, No. 6, 114-121 (2007).

32. Z. Shvidenko, E. A. Vaganov, and S. Nilsson, "The Biospheric Role of Russian Forests at the Beginning of the Third Millennium: Carbon Budget and the Kyoto Protocol," Sib. Ekologich. Zh., No. 6, 649-658 (2003).

33. S. V. Shibareva, Extended Abstract of Candidate's Dissertation in Biology (Novosibirsk, 2004).

34. L. L. Shishov, N. V. Komov, A. Z. Rodin, et al., The Soil Cover and Land Resources of the Russian Federation (Pochven. Inst. im. V.V. Dokuchaeva, RASKhN, Moscow, 2001) [in Russian].

35. L. S. Shugalei, Extended Abstract of Doctoral Dissertation in Biology (Krasnoyarsk, 1991).

36. D. G. Schepaschenko and M. V. Schepaschenko, "Carbon Reseerves in Litter and Aboveground Phytomass of Larch Stands in the Northeast of Yakutia," Lesn. Khoz., No. 5, 36-37 (2000).

37. D. Yurkevich and E. P. Yaroshevich, Biological Productivity of Different Types and Associations of Pine Forests (Nauka i tekhnika, Minsk, 1974) [in Russian]. 
38. P. V. Bolstad and J. M. Vose, "Forest and Pasture Carbon Pools and Soil Respiration in the Southern Appalachian Mountains," For. Sci. 51, 372-383 (2005).

39. Carbon Storage in Forests and Peatlands of Russia, General Technical Report NE-244 (USDA, Forest Service, Northeast Research Station, Radnr, PA,1998).

40. C. C. Cleveland, A. R. Townsend, S. K. Schmidt, et al., "Soil Microbial Dynamics and Biogeochemistry in Tropical Forests and Pastures, Southwestern Costa Rica," Ecol. Applic. No. 13, 314-326 (2003).

41. D. A. Martens, T. E. Reedy, and D. T. Lewis, "Soil Organic Carbon Content and Composition of 130-Year Crop, Pasture and Forest Land-Use Managements," Gl. Change Biol. No. 10, 65-78 (2004).

42. S. Nilsson, A. Shvidenko, V. Stolbovoi, et al., Full Carbon Account for Russia, Interim Rep. IR-00-021 (Laxenburg, Austria, 2000) [http://www.iiasa.ac.at/Publications/Documents/IR-00-021.pdf].

43. C. H. Racine, "Tundra Fire Effects on Soils and Three Plant Communities along a Hill-Slope Gradient in the Seward Peninsula, Alaska," Arctic, No. 34(1), 71-84 (1981).

44. V. A. Rozhkov, V. B. Wagner, B. M. Kogut, et al., Soil Carbon Estimates and Soil Carbon Map for Russia (IIASA, Laxenburg, 1996).

45. D. Schepaschenko, I. McCallum, A. Shvidenko, et al., "A New Hybrid Land Cover Dataset for Russia: A Methodology for Integrating Statistics, Remote Sensing and In Situ Information," J. Land Use Sci., No. 6(4), 245-259 (2011).

46. T. E. Staley, J. M. Gonzalez, and J. P. S. Neel, "Conversion of Deciduous Forest to Sylvopasture Produces Soil Properties Indicative of Rapid Transition to Improved Pasture," Agroforest Syst, No. 74, 267-277 (2008).

47. V. Stolbovoi, "Carbon in Russian Soils," Clim. Change, No. 55, 131-156 (2002).

48. V. Stolbovoi, "Soil Carbon in the Forests of Russia," Mitig. Adapt. Strat. Gl. Change, No. 11, 203-222 (2006).

49. V. Stolbovoi and I. McCallum, Land Resources $f$ Russia (IIASA, Laxenburg, 2002) [http://www.iiasa.ac.at/Research/FOR/russia_cd/index.htm]

50. C. Tarnocai, J. G. Canadell, E. A. G. Schuur, P. Kuhry, G. Mazhitova, and S. Zimov, "Soil Organic Carbon Pools in the Northern Circumpolar Permafrost Region," Gl. Biogeochem. Cycles, GB2023 (2009).

51. T. S. Vinson and T. P. Kolchugina, "Pools and Fluxes of Biogenic Carbon in the Former Soviet Union," Water Air Soil Pollut., No. 70, 223-237 (1993). 